\title{
Cytotoxic Activity of Ethanolic Extract of Cuminum cyminum Linn Against Seven Human Cancer Cell Line
}

\author{
Ekta Prakash", Dwijendra Kumar Gupta \\ Department of Biochemistry, Allahabad University, Allahabad, India \\ *Corresponding Author:ekta_prakash1@hotmail.com
}

Copyright $@ 2014$ Horizon Research Publishing All rights reserved.

\begin{abstract}
The objective of the present study is to evaluate the cytotoxic activity of Cuminum cyminum Linn ethanolic extract using in-vitro study. Following seven human cancer cell lines Colon 502713, Colo-205, Hep-2, A-549, OVCAR-5, PC-5, SF-295 were taken. The anti-cancer properties of cumin seed was determined using SRB assay. Activity was found to be $25 \%, 61 \%, 40 \%, 31 \%, 31 \%, 28 \%$, 27\% against SF-295, Colon 502713, Colo-205, Hep-2, A-549, OVCAR-5, PC-5 human cancer cell lines respectively. Cuminum cyminum Linn extract showed $61 \%$ maximum activity against Colon 502713 cell line.
\end{abstract}

Keywords Ethanolic Extract, Cuminum Cyminum, Colo502713, SRB Assay

\section{Introduction}

Cancer is a major cause of death and the number of new cases, as well as the number of individuals living with cancer, is expanding continuously. Due to the enormous diversity of plants that synthesize mixtures of structurally different bioactive compounds, the plant kingdom is potentially a very diverse source of chemical constituents with tumor cytotoxic activity. Despite the successful utilization of few phytochemicals, such as vincristine and taxol, into mainstream of cancer chemotherapy, commercial plant-derived anti-cancer formulations represent only one-fourth of the total repertoire of the available treatment options. Though significant progress has been made towards the characterization of isolated compounds and their structure-related activities, the complex composition of plant extracts, along with the lack of reproducibility of activity and the synergy between different, even unidentified, components of an extract, prohibits the full utilization of plants in pharmaceutical research. A total of 187 plant species, belonging to 102 genera and 61 families have been identified as an active or promising source of phytochemicals with antitumor properties, corresponding to a 41 percent increase during the last five years. Among them, only 15 species (belonging to ten genera and nine families) have been utilized in cancer chemotherapy at a clinical level, whereas the rest of the identified species are either active against cancer cell lines or exhibit chemotherapeutic properties on tumor-bearing animals under experimental conditions. The outlook of phytochemistry based cancer therapy is discussed, particularly in the perspective of identifying immunomodulatory anti-cancer agents with minimal toxicity on healthy tissues

Cuminum cyminum Linn. belongs to the family Umbelliferae. The common English name is Cumin. It is native of Mediterranean region. In India, it is cultivated mainly in the Punjab and Uttar Pradesh. The plant is a short annual herb with small pinkish flowers. The elongated oval fruit are aromatic and light brown in colour. The fruit is a good source of thymol; it is stomachic, diuretic, carminative, stimulant and astringent. It is prescribed in dyspepsia, diarrhea and hoarseness of voice. It is given for promoting secretion of milk. We studied this plant for possible anti-cancer activity using SRB assay against seven human cancer cell lines.

\section{Materials and Methods}

\subsection{Preparation of Cuminum Cyminum Linn Ethanolic Extract}

The seed part was ground $(500 \mathrm{~g})$ to a fine powder and was placed in a glass percolator of appropriate size. Sufficient quantity of solvent was added to submerge the plant material. After standing for about 16 hours percolate was collected and filtered if required. The process was repeated four times for exhaustive extraction of the plant material. The ethanolic extract was concentration under reduce pressure at $50^{\circ} \mathrm{C}$ using rotavapor and round bottom flask. The final drying was done in a vacuum desicator. The extract was transferred to glass container of appropriate size. This form the stock extract.

\subsection{Source of Human Cancer Cell Line}


Human cancer cell line were obtained from National Centre for cell science, Pune-411007(India) and National Cancer Institute, DTCD, Fredrick Cancer Research and Development Centre, Fairview centre, Suite 205, 1003, West $-7^{\text {th }}$ Street Frederick MD-21701-8527(USA)

\subsubsection{Selection of Human cancer cell line}

The cell line were selected in such a way that almost all the cell line grow on a single growth medium (RPMI-1640) in tissue culture flask (TCP) and the mass doubling time was such that enough cell were obtained for screening. Cell which were used were free from bacteria, yeast, mould, mycoplasma and in special cases from viruses at all the stages. If contamination appeared at any stage, the stock in which it occurred was discarded immediately. Cancer of central nervous system CNS, Lung cancer cell line A-549, Colon cancer cell lines, Colo-205, Colon 502713, Liver cancer cell line, Hep-2, Ovarian cancer cell line, OVCAR-5, Prostrate cancer cell line PC-5 were taken for the study.

\subsection{Procedure for In Vitro Cytotoxicity of Cuminum Cyminum Linn Extract}

Cytoxicity of test sample was performed against seven human cancer cell lines. 96 well flat bottom tissue culture plates were taken. There were four types of well in TCP, control blank (CB, without cells, complete growth medium only) and control growth (GC, with cell in absence of test material) to determine $100 \%$ growth. The growth in the presence of test material was determined from the difference of test growth (GT, cell with test material) and test control (CT, test material without cells).

The desired human cancer cell lines were grown in tissue culture flask at $37^{\circ} \mathrm{C}$ in an atmosphere of $5 \%$ in $\mathrm{CO}_{2}$ and $90 \%$ relative humidity in complete growth medium to obtain enough number of cells. The cells were harvested by the treatment of trypsin-EDTA and complete growth medium added. Viable cells were counted in haemocytometer by using trypan blue. Viable cell density was adjusted 500040,000 cells/100 $\mu \mathrm{l}$ depending upon the cell line (Monks et al 1991). Cell suspension $100 \mu \mathrm{l}$ was added. Complete growth medium was added and incubated at $37^{\circ} \mathrm{C}$ for 24 hours in an atmosphere of $5 \% \mathrm{CO}_{2}$ and $90 \%$ relative humidity in a $\mathrm{CO}_{2}$ incubator. After 24 hours test material was added. Plates were incubated at $37^{\circ} \mathrm{C}$ for 48 hours in an atmosphere of $5 \% \mathrm{CO}_{2}$ and $90 \%$ relative humidity in a $\mathrm{CO}_{2}$ incubator. The growth was determined after 48 hours by SRB assay.

\subsubsection{SRB assay}

SRB assay was carried out as described by Skehan et al., 1990, using SRB dye. After 48 hours incubation of cells with test material, the plates were taken out and $50 \mu \mathrm{l}$ of chilled $50 \%$ TCA was gently layered on top of the medium in all the wells to produce a final concentration of $10 \%$. After that Tissue culture plate were incubated at $4^{\circ} \mathrm{C}$ in a refrigerator to fix the cells attached to the bottom of the wells. After one hour the plates were taken out from refrigerator and all the contents of all the wells were pipetted out and supernatant was discarded. The plates were washed five times with distilled water to remove TCA growth medium, low molecular metabolites, serum protein etc. For washing, the wells of Tissue culture plates were filled with distilled water and the liquid in the wells was discarded by sharply flicking plate over sink. Plates were air dried and can be stored until use. SRB solution $(100 \mu 1)$ was added to each well of the plates and the plates were incubated for 30 minutes at room temperature. The unbound SRB was removed quickly (to avoid desorption of protein bound dye) by washing the wells of the plates five times with $1 \%$ acetic acid. Plates were than air dried. After that Tris buffer $(100 \mu \mathrm{l} /$ well $)$ was added in the plates. The plates were gently stirred for 5 minutes on a mechanical shaker and optical density was recorded on ELISA reader at $540 \mathrm{~nm}$.

\section{Results}

Standard protocol was followed for bioassay as described above in Materials and Methods heading. In vitro cytotoxicity against human cancer cell lines was determined by SRB assay. In our in vitro study of anti-cancer properties of ethanolic extract of Cuminum cyminum Linn $25 \%, 61 \%, 40 \%, 31 \%, 31 \%, 28 \%, 27 \%$ activity was found against SF-295,Colon 502713, Colo-205, Hep-2,A-549,OVCAR-5,PC-5 human cancer cell lines respectively. Maximum activity was observed against Colon $502713(61 \%)$ as shown in the table 1.

Table1. Cytotoxic activity of ethanolic extract of Cuminum cyminum Linn against seven human cancer cell lines at $100 \mu \mathrm{g} / \mathrm{ml}$

\begin{tabular}{|c|c|c|c|c|c|}
\hline S.No & Tissue used & Types of cell lines used & Extract & Conc. $\mu \mathrm{g} / \mathrm{ml}$ & $\%$ Growth Inhibition \\
\hline 1 & CNS & SF-295 & Ethanolic & 100 & $25 \%$ \\
\hline 2 & Colon & Colon502713 & Ethanolic & 100 & $61 \%$ \\
\hline 3 & Colon & Colon 205 & Ethanolic & 100 & $40 \%$ \\
\hline 4 & Liver & Hep-2 & Ethanolic & 100 & $31 \%$ \\
\hline 5 & Lungs & A-549 & Ethanolic & 100 & $31 \%$ \\
\hline 6 & Ovary & OVCAR-5 & Ethanolic & 100 & $28 \%$ \\
\hline & Prostrate & PC-5 & Ethanolic & 100 & $27 \%$ \\
\hline
\end{tabular}




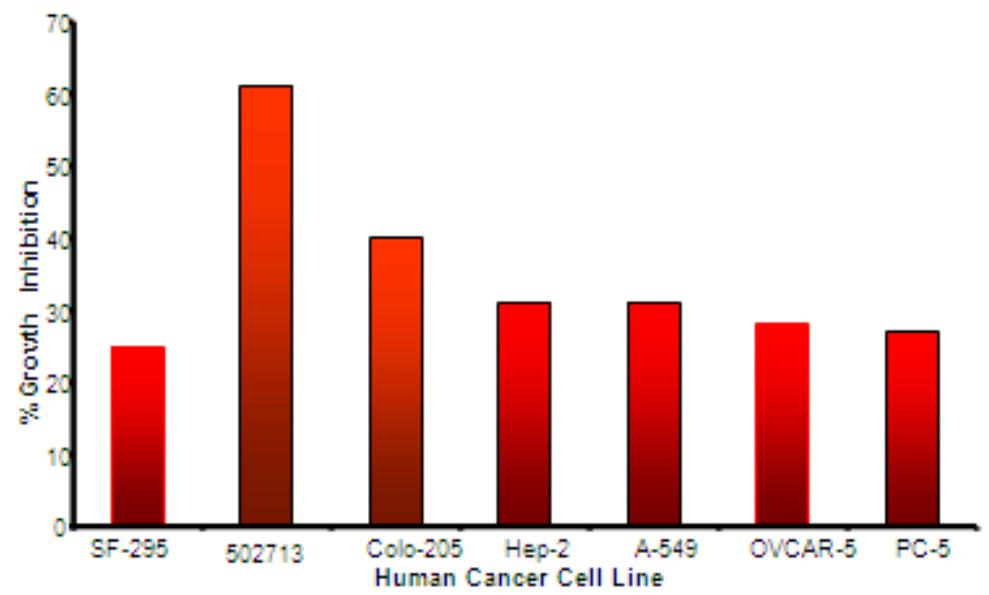

Figure 1. The cytotoxic activity shown by the ethanolic extract of Cuminum cyminum activity against all cell lines SF-295, Colon 502713, Colo-205, Hep-2, A-549, OVCAR-5, PC-5 were $25 \%, 61 \%, 40 \%, 31 \%, 31 \%, 28 \%, 27 \%$ respectively. The activity was maximum $61 \%$ against Colon 502713 cell line

\section{Discussion}

In recent years, considerable interest has been generated on identifying naturally occurring chemopreventive substances capable of inhibiting or reversing the multistage carcinogenesis. A wide array of phenolic substances particularly those present in dietary and medicinal plants have been reported to possess substantial anti-carcinogenic and anti-mutagenic activities. The majority of these naturally occurring phenolics have anti-oxidative and anti-inflammatory properties, which possibly contribute to their chemopreventive properties. Many of the natural products from a large number of aromatic and medicinal plants have found use in household treatment of a variety of elements. These products hold a great promise as new sources of drugs that have been used effectively for centuries for traditional medicine. Medicinal properties of these plants are due to presence of some active principal that produce definite biologic activity receptors or cells etc. causing interference in some essential biologic pathway or by some other mechanism in the context of their antimicrobial activity.

The cancer chemopreventive potential of cumin seed could be attributed to its ability to alter carcinogen metabolism. Current studies have shown that cumin seeds have also anti-carcinogenic properties. The detoxification and chemo-preventive properties increase secretion of anti-carcinogenic enzymes from the glands. The anti-oxidants like limonene present in Cumin have strong anti-tumor properties. Recent research has also publicized that cumin may prevent the growth of breast and colon cancer cells.

Gagandeep et al., 2003, reported a strong correlation between diet and cancer. For ages, cumin has been a part of the diet. It is a popular spice regularly used as a flavoring agent in a number of ethnic cousins. In this study, cancer chemopreventive potentials of different doses of a cumin seed-mixed diet were evaluated against benzo(a)pyrene
$[\mathrm{B}(\mathrm{a}) \mathrm{P}]$-induced stomach tumorigenesis and 3-methylcholanthrene (MCA)-induced uterine cervix tumorigenesis. Results revealed significant inhibition of stomach tumor by cumin.

According to Amal A.I. Mekawey, Mokhtar M.M. and Rasha M. Farrag (2009) cumin seed extract showed activity against six tumor cell lines as well as against four Gram negative and four Gram-positive bacterial pathogens. They found antitumor effect of the EHP compound of Cuminum cyminum seeds against six cell lines (HEPG2; HELA; HCT116; CACO2; MCF7; HEP2).

In our in vitro study of anti-cancer properties of ethanolic extract of Cuminum cyminum Linn $25 \%, 61 \%, 40 \%, 31 \%, 31 \%, 28 \%, 27 \%$ activity was found against SF-295, Colon 502713, Colo-205, Hep-2,A-549,OVCAR-5,PC-5 respectively. Maximum activity was observed against Colon 502713 (61\%) human colon cancer cell line.It is worth noting that according to the available research, no previous work has been reported on the antitumor activity of the seeds of Cuminum cyminum. Regarding its antitumor activity, the SRB assay of ethanolic extract of Cuminum cyminum treated cells showed that at $100 \mu \mathrm{g} / \mathrm{ml}$ concentration of the extract, $61 \%$ activity noted in Colon502713 cell line while other cell lines namely Colo-205, Hep-2, and A-549 showed 40\%, 31\%, 31\% activity respectively. This study conveys the use of cumin as a helper in the therapy or the control of the cancer of Colon, liver and prostrate. Cumin use in diet may reduce the risk of cancer. It has preventive properties against cancer as shown in the study of Colon cancer cell line

\section{Acknowledgements}

I would like to thank senior scientist Dr.Ajit. K.Saxena, Indian Institute Of Integrative Medicine (C.S.I.R Lab), Tawi, Jammu, India for providing us human cancer cell lines and giving infrastructural facility to perform my experiments 
without which such study on cancer would have not been possible.

\section{REFERENCES}

[1] Ahluwalia, v. K., Sharma, N.D., Mittal, B. and (Late) Gupta, S. R. (1988) Flavanoids from Kamala tree. Ind J Chem. 27, p. 238.

[2] Ahmad, B., Alam, T., Varshney, M. and Khan, S. A. (2002) Hepatoprotective activity of two plants belonging to the Apiaceae and the Eurphorbiaceae family. J Ethnopharmacol. 79, p. 313.

[3] Ahmad, I., Mehmood, Z. and Mohammad, F. (1998) Screening of some Indian medicinal plants for their antimicrobial properties. J Ethnopharmacol.62, p. 183.

[4] Ahmad, I., Mahmood, M., Mohammad, F. and Ahmad, S. (2001) Antimicrobial potency and synergistic activity of five traditionally used Indian medicinal plants. J Med and Aromat Plant Sci. 23, p. 173

[5] Amal A.I. Mekawey, Mokhtar M.M. and Rasha M. Farrag,.Antitumor and Antibacterial Activities of [1-(2-Ethyl, 6-Heptyl) Phenol] from Cyminum Seeds,Journal of Applied Sceiences Research,5(11):1881-1888,2009

[6] Baker JT, Borris RP, Carte B, Cordell GA, Soejarto DD, Cragg GM, Gupta MP, Iwu MM, Madulid DR, Tyler VE (1995) Natural product drug discovery and development: new per-spectives on international collaboration. J Nat Prod 58:1325-1357.

[7] Akiko, K. M., Hiroshi, K., Fumiko, K., Yasushi, T. and Tohru, K. (1992) Woodfordin C, a new inhibitor of DNA topoisomerase II. J. Ind Pharmacol. 44, p. 1961.

[8] Bravo.L. (1998) Polyphenols: Chemistry, dietary sources, metabolism, and nutritional significance. Nutr Rev $56: 317-333$

[9] Gagandeep S, Dhanalakshmi S, Mendiz E, Rao AR, Kale RK. Chemopreventive effects of Cuminum cyminum in chemically induced fore stomach and uterine cervix tumors in murine model systems. Nutr Cancer. 2003; 47:171-80.

[10] Ekta Prakash (2013),Book "Analytics Of Some Medicinal And Latex Bearing Plants For Possible Anticancer And Anti-arthritic Properties Using In-vitro Studies".Lap Lambert Academic Publishing

[11] EL-Mrezabani, M.M., A.A. EL-Aaser, M.A. Attia, A.K. EL-Duweini and A.M. Ghazal, 1999.Screening system for Egyptian plants with potential Anti-tumor activity. J. Med. Plant. Res., 36: 150-155.

[12] El-Shemy, H.A., S.I. Issa and K. Fujita, 2003. The effect of willow leaf extracts on human leukemic cells in vitro. J. Biochem. Mol. Biol. 36(4):387-389.

[13] Erturk, O., 2006. Antibacterial and antifungal activity of ethanolic Extracts from eleven spice plants. Biologia-Section Cellular and Molecular Biology, 61(3): 275-278.

[14] Hirano, T., M Gotoh and K.Oka, 1994. Natural flavonoids and lignans are potent cytostatic agents against human leukemic HL-60 cells. Life Sci., 55 (13): 1601-1069.

[15] Jemal, A., T. Murray, A. Ghfoor, E.J. Feuer and M.J. Thun, 2005. Cancer statistics. CA. Cancer J. Clin., 55(1): 10-30. 18. Jiao, Y. and J. Y Sun, 1990.Studies on chemical compositions of volatile oil from seeds Of Cuminum cyminum L. Acta Botanica Sinica, 32(5): 372-375.

[16] Kristin, R., D. Chen, K. Bimal and Q. Pingdou, 2005. Apoptotic-inducing activity of novel polycyclic aromatic compounds in human leukemic cells. International Journal of Molecular Medicine, 17: 931-935.

[17] Kusumoto, I.T., T. Nakabayashi and K. Shimotohno, 1995. Screening Of various plant extracts used in ayurvedic medicine for inhibitory effects on human immunodeficiency virus type 1(HIV-1) protease. Phytotherapy Research, 9: 180-184.

[18] Mosmann, T., 1983. Rapid colorimetric assay for cellular growth and survival: application to proliferation and cytotoxicity assays. J Immunol. Methods, 65: 55-63.

[19] Nag, L.K, V.S. Rajora and D.K. Gupta, 2006. Evaluation of in-vitro Activity of some herbs against E. coli. Phytomedica, 7: 89-91.

[20] Nicola, S.I., L.C. Pietro and S. Felice, 2005.Antibacterial activity of Cuminum cyminum L. and Carum carvi L. essential oils. J. Agric. FoodChem., 53(1): 57-61.

[21] Nozaki, H., Y. Matsura, S. Hirano, J.J. Chang and K. Hsiunglee, 1990. Antitumor agents, 116, Cytotoxic triterpenes from Maytenus diversifolia. Nat. Prod., 53(4): 1039-1045.

[22] Oiye, S.O. and N.M. Muroki, 2002. Use of Spices in Foods. The Journal of Food Technology in Africa, 7: 39-44.29. Peter, K.V., 1999. Spices research in India. Indian Journal of Agricultural Sciences, 68: 527-532.

[23] Peter, T., I. Cesari, M. Arsenak and D. Ballen, 2006. Evaluation of Venezuelan medicinal plant extracts for antitumor and antiprotease activities. Pharmaceutical Biology, 44(5): 349-362.

[24] Rajan, M.R. and M. Nagaraj, 2006. Antimicrobial activity of selected spices. Asian Journal of Microbiology, Biotechnology and Environmental Sciences, 8: 647-650.

[25] Monks, A., Scudiero, D., Skehan, P., Shoemaker, R., Paull, K., Vistica, D., Hose, C., Langley, J., Cronisc T., Vaigro -Wolff, A., Gray -Goodrich, M., Campbell, H., Maya, J. and Boyd, M. (1991) Feasibility of a high -flux anticancer drug screen using a diverse panel of cultured human tumor cell lines. J Natl Cancer Inst. 83, p. 757.

[26] Skehan, P., Storeng, R., Scudiero., D., Monks, A., McMohan, J., Vistica, D., Warren, J.T., Bokesh, H., Kenny, S. and Boyd, M. (1990) New colorimetric cytotoxcity assay for anticancer drug screening. J Natl Cancer Inst. 82, p. 1107.

[27] Skehan, P. et al. (1990). New Colorimetric Cytotoxicity Assay for Anticancer-Drug Screening. J. Natl. Cancer Inst., 82: 1107-1112. 20. 